\title{
An investigation of green tea's effect on mackerel (Scomber Scombrus)'s protein structure during frozen storage by FT-Raman spectroscopy
}

\author{
Rabia Alghazeer ${ }^{*}$, Wafa S. Alansari ${ }^{2}$, Ghalia Shamlan ${ }^{3}$, Areej A. Eskandrani ${ }^{4}$, Nazlin \\ K. Howell ${ }^{5}$ \\ ${ }^{1}$ Dept. of Chemistry, Faculty of Sciences, University of Tripoli, Tripoli 50676, Libya. \\ ${ }^{2}$ Dept. of Biochemistry, Faculty of Science, University of Jeddah, Jeddah 21577, Saudi Arabia \\ ${ }^{3}$ Dept. of Food Science and Nutrition, College of Food and Agriculture Sciences, King Saud \\ University, Riyadh 11362, Saudi Arabia. \\ ${ }^{4}$ Dept. of Chemistry, Faculty of Science, Taibah University, Medina 30002, Saudi Arabia. \\ ${ }^{5}$ School of Biomedical and Molecular Sciences, University of Surrey, Guildford, Surrey, \\ United Kingdom GU2 $7 X H$. \\ *Corresponding author:R.alghazeer@uot.edu.ly
}

\begin{abstract}
FT-Raman spectroscopy (FT-RS) was used to investigate green tea's potential protective effect as an antioxidant during frozen storage of Atlantic mackerel (Scomber scombrus). Atlantic mackerel was stored for more than 26 weeks at $-10^{\circ} \mathrm{C}$ or $-80^{\circ} \mathrm{C}$ (control), with or without green tea (GT). Raman analysis showed substantial changes in protein structure due to frozen storage, especially at the higher storage temperature $\left(-10^{\circ} \mathrm{C}\right)$, compared with the findings at $-80^{\circ} \mathrm{C}$ or $-10^{\circ} \mathrm{C}$ with instant GT, indicated by a decrease in the tyrosine doublet ratio, a-helix content. $\mathrm{O}-\mathrm{H}$ stretching band intensity, along with an increase in tryptophan band intensity and $\beta$-sheet structure. GT as an antioxidant at a concentration of $\sim 250 \mathrm{ppm}$ can protect the structure of fish proteins for a limited storage period. However, for optimal freshness, fish should be stored at very low temperatures.
\end{abstract}

Keywords: Atlantic mackerel; frozen fish; green tea; lipid peroxidation; Raman spectroscopy.

\section{Introduction}

Freezing and frozen storage are the major methods for protecting fish for extended periods; however, they can induce many changes. For example, studies reported that changes were induced in crushed fish by reduced muscle integrity, thus, permitting close interaction between cellular compounds and introduced oxygen (Hultin \& Kelleher, 2000; Sharanagat et al., 2019). Alterations in the texture of fish muscle by frozen storage yield hard, dry, and fibrous products (Badii \& Howell, 2002; Romotowska et al., 2016; Saeed \& Howell, 2002). These textural changes are mainly attributed to the denaturation and aggregation of myofibrillar proteins caused by ice crystals and lipid oxidation in tissues (Badii et al., 2004; Pereira de Abreu et al., 2012).
Fish muscle contains efficient antioxidants, such as alpha-tocopherol (vitamin E), which stabilize unsaturated lipids. However, antioxidants lose their activity due to the consumption of antioxidants during the oxidative process (Rudy et al., 2016). Adding natural antioxidants (vitamin $\mathrm{C}$, vitamin $\mathrm{E}$, and rosemary) to fish muscle substantially minimizes protein denaturation, toughening, and lipid oxidation (Badii \& Howell, 2000; Elgamouz et al., 2019). Natural antioxidants, including green tea (GT) polyphenols, have also been effective for preventing lipid peroxidation and thus inhibit protein denaturation and textural changes in chilled fish stored at $4^{\circ} \mathrm{C}$ for 10 days (Bora et al., 2018; Tang et al., 2001). Many spectroscopic 
procedures, including Raman, infrared, and NMR spectroscopy, have been used to evaluate the quality of frozen stored fish. Raman spectroscopy (RS) has been considered an important analytical method within different biological and medical applications as it is non-destructive and, in principle, requires no sample preparation. In the food sector, RS is particularly valuable for measuring changes in proteins and intact tissues. The efficiency of RS depends on precise vibrational assignments for different bands in the spectrum, which are provided by the protein backbone and various side chains. RS can powerfully analyse proteins' secondary structures and provide details about amino acids in protein side chains (Howell et al., 2001; Li-Chan et al., 1994; Mandrile et al., 2016). The prominent protein bands assigned to skeletal stretching styles of groups are rich in electrons that affect the vibrational spectrum, such as vibrations related to the aromatic rings of tyrosine (Tyr), phenylalanine (Phe), tryptophan (Trp), and sulfur-containing cysteine (Cys) side chains. Also, the amide region has been used to characterize the secondary structure of proteins such as myosin, lysozyme (Diarrassouba et al., 2015; Howell \& Li-Chan, 1996), casein (Byler and Susi, 1988), whey and egg proteins (Fan et al., 2019; Ngarize et al., 2004).

Tyr and Trp vibrational bands are sensitive to the microenvironment. Therefore, methods such as analyzing the differences in vibrational mode intensity and changes in the intensity ratio of Fermi resonance doublets have been used to obtain comprehensive information about aromatic side chains in the microenvironment. An example is the occurrence of a Fermi doublet, which is important in biochemistry and involves a pair of bands near 850 and 830 $\mathrm{cm}^{-1}$ observed in the spectra of many proteins. The origin of the tyrosine doublet, the relative locations of its constituents of the phenyl ring, the $\mathrm{H}$-bonding of phenolic $\mathrm{OH}$, and the amino acid backbone conformation have been investigated (Jenkins et al., 2005). RS has been used to trace the variations in frozen fish muscle. Structural alterations were reported in proteins throughout frozen storage and a decline in $\alpha$-helices and an elevation in the level of $\beta$-sheets because of contact with hydrophobic aliphatic side chains (Badii \& Howell, 2002; Herrero et al., 2004; Xiong et al., 2016). The protein structure changes can be changed because some polar amino acid-like tyrosin is exposed on the protein surface and interacts with water molecules as a hydrogen bond donor or acceptor.

Therefore, the major spectral features of the water Raman spectrum in fish muscle were examined by studying the 3100 and 3500 $\mathrm{cm}^{-1}$ regions associated with stretching in the OH group. Howell et al., 2001, found that the vibrational modes of D2O $\left(2400 \mathrm{~cm}^{-1}\right)$ were affected by corn oil in a lysozyme-corn oil emulsion.

Thus, in food emulsions, oil can affect water molecules and their structure, influencing protein groups and hydrophobic interactions. A small range of the spectrum (under 600 $\mathrm{cm}^{-1}$ ) is associated with stretching and bending vibrations of the $\mathrm{O}(\mathrm{N})-\mathrm{H} \ldots \mathrm{O}(\mathrm{N})$ units, which display intermolecular fluctuation bands resulting from connections between $\mathrm{H}$-bonded water and biomolecules (Colaianni \& Nielsen, 1995; Yamamoto et al., 2019). To obtain information about the Raman spectrum, it was essential to classify marker bands representing protein interactions and structure. In this study, FT-RS was used to investigate GT's potential protective effect as an antioxidant during the frozen storage of Atlantic mackerel.

\section{Materials and methods}

M \& J Seafood (Farnham, UK) provided 80 matched deboned and skinned (about $6 \mathrm{Kg}$ ) Atlantic mackerel (Scomber scombrus) fillets. Tokyo Nikken Foods Co. (Japan) provided the GT.

\subsection{Sample preparation}

To simplify the mixing of the antioxidants, the fillet samples were crushed and then separated into groups. One group was frozen at $-80^{\circ} \mathrm{C}$, the second group was frozen at $-10^{\circ} \mathrm{C}$ and deprived of antioxidants and considered a 
negative control. In contrast, third and fourth groups were mixed with GT at a rate of 250 or $500 \mathrm{ppm}$, respectively, and then frozen at $-10^{\circ} \mathrm{C}$. Samples were examined at time 0 and then at 4 and 26 weeks of storage to explore the changes in protein structure throughout frozen storage.

\subsection{FT-RS measurement}

Mackerel stored at -80 and $-10^{\circ} \mathrm{C}$, with and without antioxidants, was tested in a container (FBG-Anchor, London, UK) in PerkinElmer System 2000 FT-RS with excitation from an Nd: YAG laser at $1064 \mathrm{~nm}$.

Sulfur lines at $217 \mathrm{~cm}^{-1}$ calibrated the apparatus frequency. Three sample groups were examined with a laser power of 1785 $\mathrm{mW}$. The spectrum average was 198 scans, with a corrected, smoothed, and normalized phenylalanine band intensity at $1004 \mathrm{~cm}^{-1}$ (Howell \& Saeed, 1999; Li-Chan et al., 1994). Noted spectra were examined by Grams 32 (Galactic Industries Corp., NH). The bands in the spectra relating to protein vibrational modes were examined as described previously (Careche et al., 1999; Howell \& Saeed, 1999; Li-Chan et al., 1994). Since phenylalanine shows a strong band at $1004 \mathrm{~cm}^{-1}$ for fresh and frozen muscle and is known not to be affected $\mathrm{v}$ band was used as an internal standard for normalization ( $\mathrm{Tu}, 1986)$. The results are presented as mean \pm standard deviation for each relative peak intensity of spectral bands.

\subsection{Statistical analysis}

Statistical analyses were carried out using SPSS (SPSS Inc., Chicago, IL, USA). Raman spectra of mackerel muscle were coared among groups using one-way ANOVA. A post hoc test was applied to recognize significance between groups. The results were considered statistically significant at $\mathrm{p}<0.05$.

\section{Results and discussion}

Figure 1 presents a Raman spectrum (600 $1800 \mathrm{~cm}^{-1}$ ) of fresh mackerel muscle, while Table 1 presents the assignments of the most prominent Raman signals.

Table 1. Major FT-Raman peak assignments for mackerel muscle.

\begin{tabular}{|ll|}
\hline Wavenumber region $\left(\mathbf{c m}^{-1}\right)$ & Assignments \\
760 & Trp \\
830,855 & Tyr doublet \\
937 & Helix C-C stretch, $\mathrm{CH}_{3}$ symmetric \\
& stretch \\
990 & $\beta$-sheet structure \\
1034 & Phe, ring band \\
1128 & Isopropyl anti-symmetric stretch \\
& CH stretch backbone \\
1160 & CH anti-symmetric (aliphatic) \\
& CH rock (aromatic) \\
1239 & $\beta$-sheet \\
1245 & Amide III (random coil) \\
1264 & Amide III \\
1320 & Amide II \\
1340 & H-band doublet from Trp \\
1425 & (Shoulder, residue vibration) \\
& Asp, Glu, Lys \\
1451 & Aliphatic groups, CH bend \\
1554 & Trp \\
1660 & Amide I \\
2940 & CH stretch, aliphatic \\
2888 & Shoulder \\
2976 and 2969 & Shoulder \\
\hline
\end{tabular}


$\mathrm{V}$

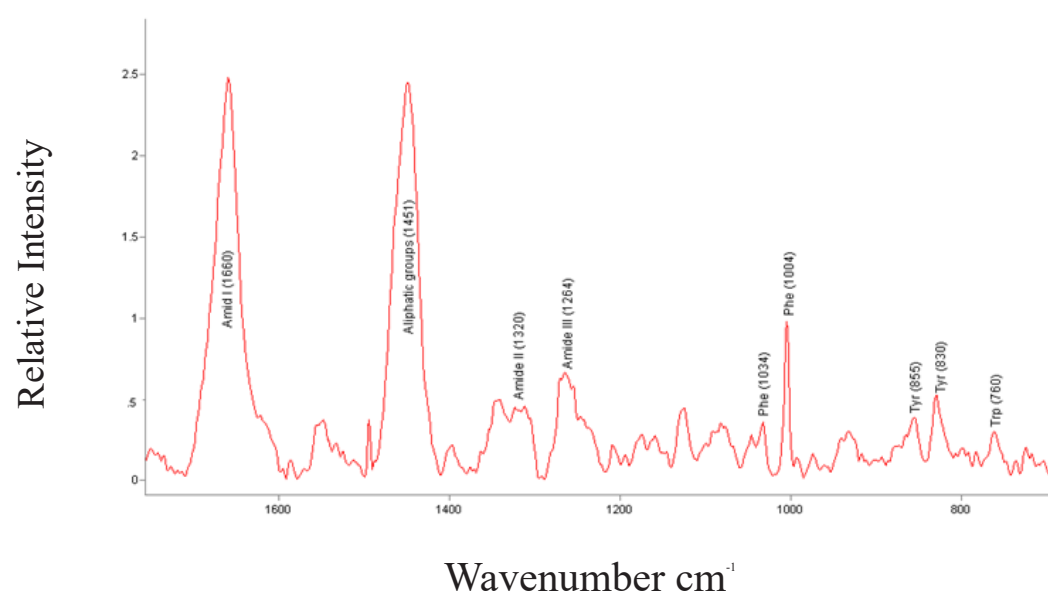

Fig.1. FT-Raman spectrum of fresh mackerel muscle in the $600-1800$ $\mathrm{cm}^{-1}$ region.

(A)

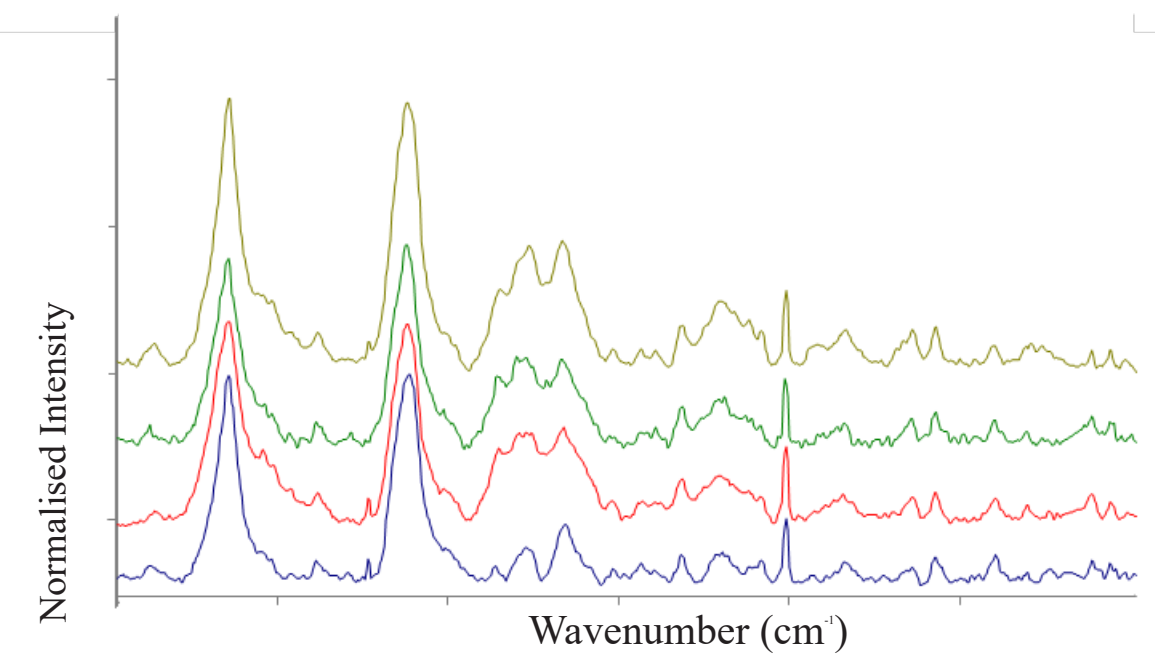

(B)

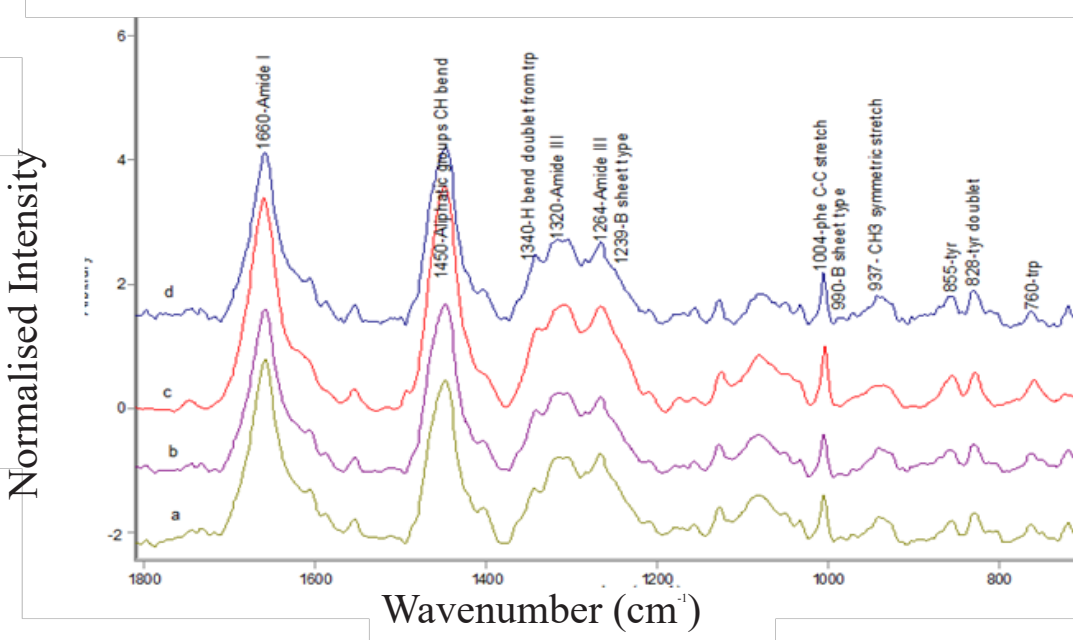

Fig. 2. FT-Raman spectra in the $600-1800 \mathrm{~cm}^{-1}$ region of mackerel muscle stored: (a) at $-80^{\circ} \mathrm{C}$, at $-10^{\circ} \mathrm{C}$ with (b) $250 \mathrm{ppm}$ instant GT or (c) $500 \mathrm{ppm}$ instant GT, and (d) at $-10^{\circ} \mathrm{C}$ without instant GT for (A) 4 weeks and (B) 26 weeks. 
Figure $2(\mathrm{a}-\mathrm{d})$ presents the Raman spectra $\left(600-1800 \mathrm{~cm}^{-1}\right)$ of fish frozen at $-80^{\circ} \mathrm{C}$ and $-10^{\circ} \mathrm{C}$ with (b) 250 ppm instant GT, (c) 500 ppm instant GT, and (d) without instant

To identify the changes in protein structure resulting from the freezing of mackerel muscle, the changes in the tyrosyl doublet bands at 850 and $830 \mathrm{~cm}^{-1}$ in Raman spectra were examined. The tyrosyl doublet band reflects the content of the phenyl ring environment, phenolic $\mathrm{OH}$ group status, and conformation of the amino acid backbone. Consideration of the comparative strengths of the doublet in model systems showed that the phenolic $\mathrm{OH}$ group is strongly hydrogen-bonded, weakly H-bonded, free, or ionized; the described Raman intensities of doublet bands identified in Raman spectra of numerous proteins were interpreted to provide details of changes in the microenvironment about the tyrosine ( $\mathrm{Li}$ Chan, 1994). When tyrosine is seen, the ratio will be high (0.9-1.45), while little relationship indicates strong H-bonding.

Frozen fish muscle displayed an overall increase in the intensity ratio of tyrosine doublet bands, in a manner dependent on storage time and temperature (Figure 3). The increase occurred mainly in the group stored at $-10^{\circ} \mathrm{C}$ with no instant GT $(0.857 \pm 0.08)$ compared with the control group stored at $-80^{\circ} \mathrm{C}(0.695 \pm$ $0.06)(\mathrm{p}<0.001)$, or the group stored at $-10^{\circ} \mathrm{C}$. With $250 \mathrm{ppm}$ instant GT $(0.698 \pm 0.003)$ $(p<0.01)$ for 4 weeks. A substantial increase in the doublet ratio bands was observed after 26 weeks of storage in all samples, but mainly in groups stored at $-10^{\circ} \mathrm{C}$ treated with $500 \mathrm{ppm}$ instant GT $(0.974 \pm 0.03)$ and left untreated $(0.987 \pm 0.17)$. The above results indicate that the hydroxyl group in the tyrosine residues participated in weak H-bonding, indicating that the protein was denatured.

Also, in this study, changes in hydrophobic and aromatic groups were investigated. The intensities of 1363,880 , and $760 \mathrm{~cm}^{-1}$ bands were used to monitor the buried and exposed tryptophan residues (Miura et al., 1991). There was a steady reduction in the intensity of the tryptophan band at $760 \mathrm{~cm}^{-1}$ during storage in all groups (Figure 4). This intensity for groups stored at $-10^{\circ} \mathrm{C}$ without instant GT was significantly lower $(0.26 \pm 0.003)$ than in the group stored at $-80^{\circ} \mathrm{C}(0.31 \pm 0.023)(\mathrm{p}<$ $0.001)$. Besides, for the untreated group, the intensity of the $760 \mathrm{~cm}^{-1}$ bands was slightly lower than for those treated with $250 \mathrm{ppm}$ instant GT $(0.29 \pm 0.007)(\mathrm{p}<0.01)$ or 500 ppm instant GT $(0.28 \pm 0.021)(\mathrm{p}<0.02)$ after 26 weeks of storage. Similar results were observed in the $1450 \mathrm{~cm}^{-1}$ band (Figure 5), assigned to methylene asymmetric bending (H-C-H) or $\mathrm{CH}_{2}$ and $\mathrm{CH}_{3}$ deformation motions. Altered hydrophobic conditions around the aliphatic and aromatic side chains were used to detect damage-related changes in protein denaturation and cross-linking (Ang \& Hultin, 1989).

A change in the secondary structure content was observed throughout storage by a decrease in the $\alpha$-helix peak intensity (939 $\mathrm{cm}^{-1}$ ) (Figure 6). This reduction was significant upon comparison with the fresh sample $(\mathrm{p}<0.05)$, but the $\alpha$-helix band they have decreased in intensity only slightly in all samples during storage. There was an increase in $\beta$-sheet peak intensity (990 and $1239 \mathrm{~cm}^{-1}$ ) (Figure $7 \mathrm{a}, \mathrm{b}$ ). The formation of $\beta$ - sheets may result from the bonding between $\mathrm{C}=\mathrm{O}$ and $\mathrm{NH}$ groups that occurs when the protein unfolds or is denatured. An elevated level of $\beta$-sheets and a reduced level of $\alpha$ - helices suggested protein-protein connections that were previously described for heat-denatured proteins (Howell \& Li- Chan, 1996; Nagrize et al.,frozen stored muscle (Yamamoto et al., 2019) Moreover, fish actomyosin (Ogawa et al., 1999), especially with frozen fish samples stored at $-10^{\circ} \mathrm{C}$ without antioxidants. Studies of protein-lipid interaction have revealed that oxidized lipids cause damage to proteins, leading to texture changes and aggregate formation in fish muscle (Badii \& Howell, 2002; Saeed et al., 2006). The amide I band, located at approximately $1655 \mathrm{~cm}^{-1}$ (Krimm \& Bandekar, 1986), was derived from C $=\mathrm{O}$ stretching and $\mathrm{N}-\mathrm{H}$ bending vibrations. In proteins with increased $\alpha$ - helix content, the amide I band s usually centered around $1645-1657 \mathrm{~cm}^{-1}$, while for proteins with 


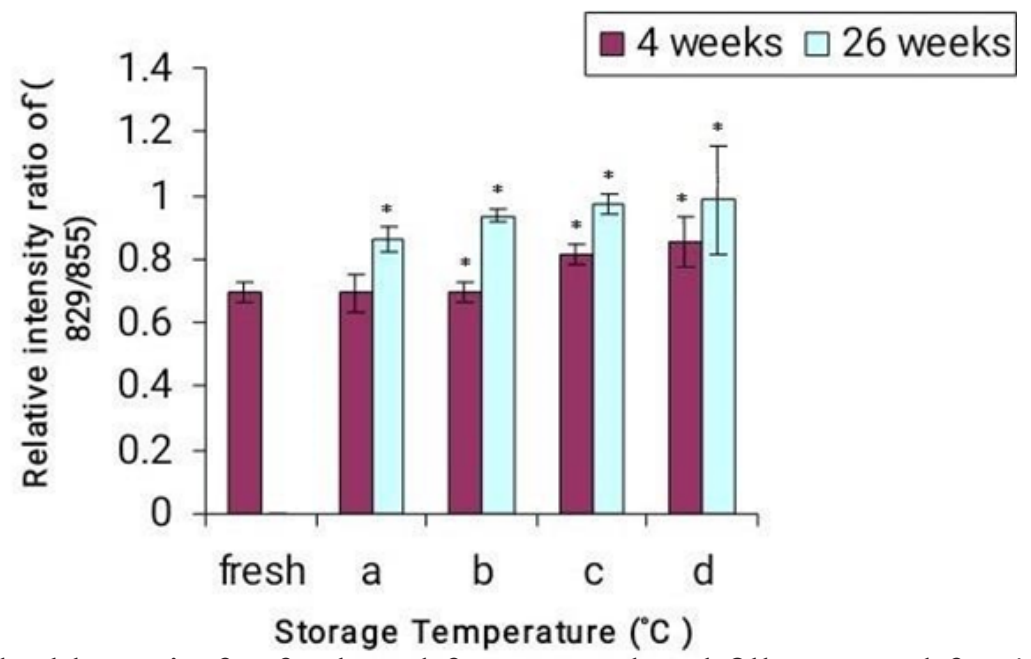

Fig. 3. Tyrosine doublet ratio for fresh and frozen mackerel fillets stored for 4 and 26 weeks: (a) at $-80^{\circ} \mathrm{C}$, at $-10^{\circ} \mathrm{C}$ with (b) $250 \mathrm{ppm}$ instant GT, or (c) 500 ppm instant GT, and(d) at $-10^{\circ} \mathrm{C}$ without instant GT. Each value is represented as mean $\pm \mathrm{SD}(\mathrm{n}=3)$, * indicates significance at $\mathrm{p}<0.05$ compared with a fresh sample.

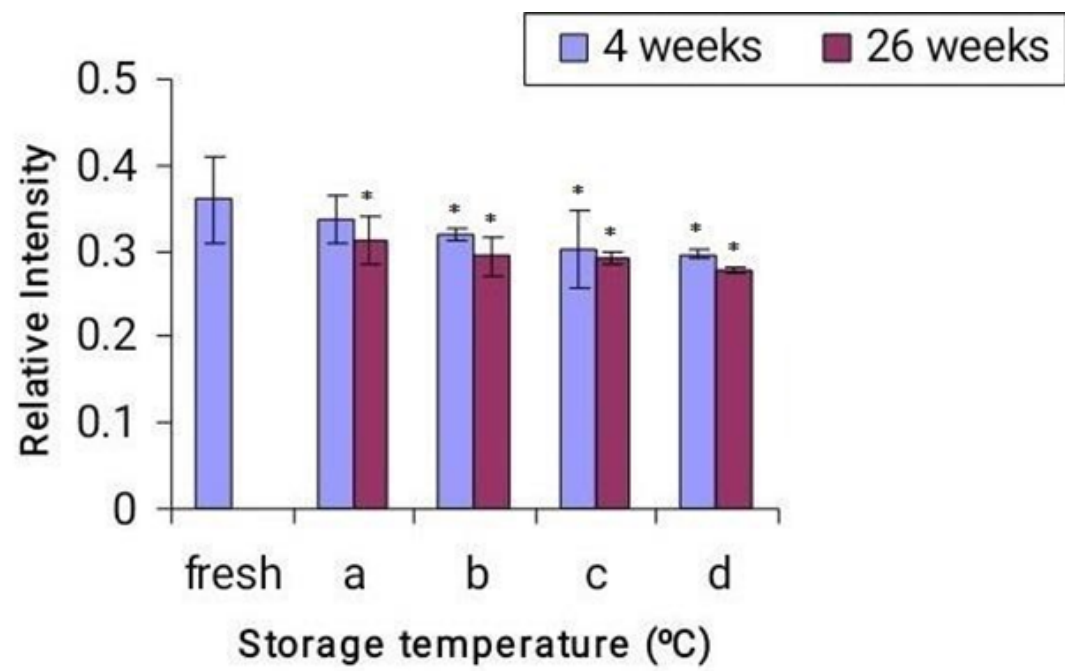

Fig. 4. Tryptophan intensity $\left(760 \mathrm{~cm}^{-1}\right)$ for fresh and frozen mackerel muscle stored for 4 and 26 weeks: (a) at $-80^{\circ} \mathrm{C}$, at $-10^{\circ} \mathrm{C}$ with (b) $250 \mathrm{ppm}$ instant GT or (c) $500 \mathrm{ppm}$ instant GT, and (d) at $-10^{\circ} \mathrm{C}$ without instant GT as a control. Each value is represented as mean $\pm \mathrm{SD}(\mathrm{n}=3)$,

$*$ indicates significance at $\mathrm{p}<0.05$ compared with a fresh sample.

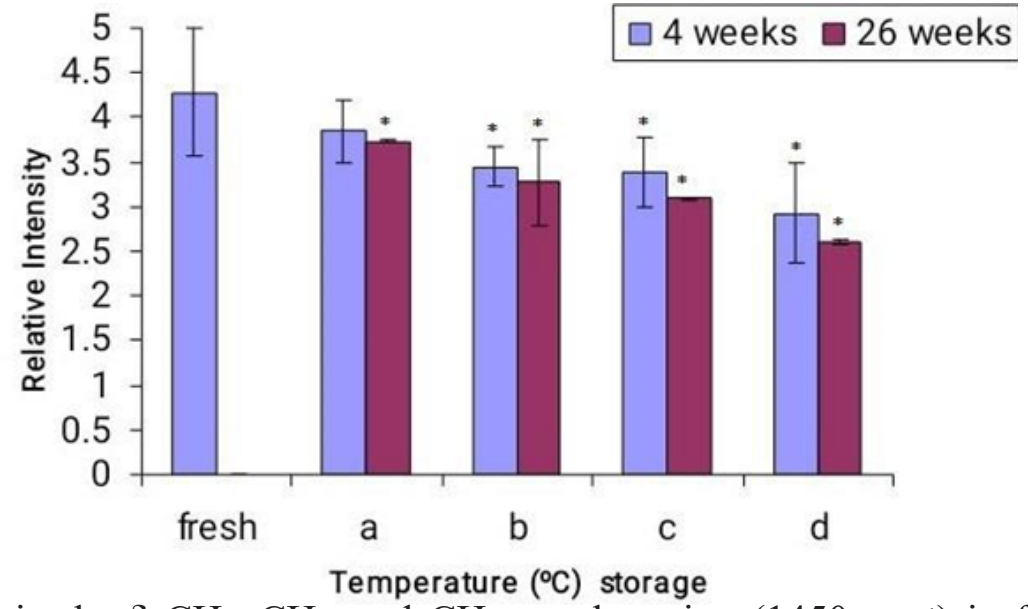

Fig. 5. Changes in the $\delta \mathrm{CH}_{3}, \mathrm{CH}_{2}$, and $\mathrm{CH}$ stretch region $\left(1450 \mathrm{~cm}^{-1}\right)$ in fresh and frozen mackerel muscle stored for 4 and 26 weeks: (a) at $-80^{\circ} \mathrm{C}$, at $-10^{\circ} \mathrm{C}$ with (b) 250 ppm instant GT or (c) $500 \mathrm{ppm}$ instant GT, and (d) at $-10^{\circ} \mathrm{C}$ (without instant GT). Each value is represented as mean \pm SD $(n=3), *$ indicates significance at $\mathrm{p}<0.05$ compared with a fresh sample. 


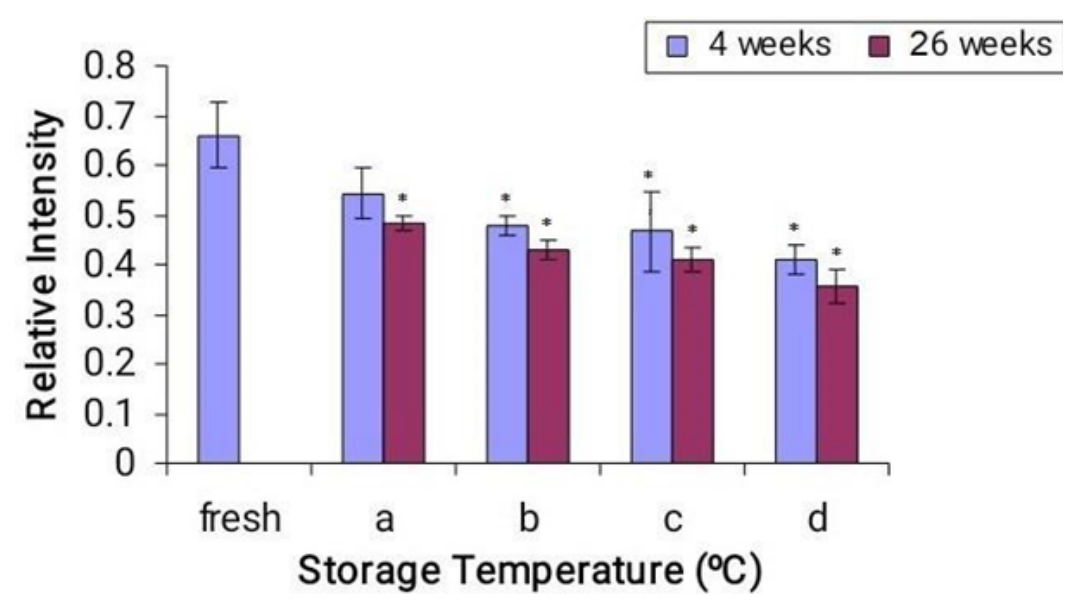

Fig. 6. $\alpha$-helix structure from a Raman band $\left(939 \mathrm{~cm}^{-1}\right)$ for fresh and frozen mackerel muscle stored for 26 weeks: (a) at $-80^{\circ} \mathrm{C}$, at $-10^{\circ} \mathrm{C}$ with (b) $250 \mathrm{ppm}$ instant $\mathrm{GT}$ or (c) with $500 \mathrm{ppm}$ instant GT, and (d) at $-10^{\circ} \mathrm{C}$ without instant GT. Each value is represented as mean $\pm \mathrm{SD}(\mathrm{n}=3)$, * indicates significance at $\mathrm{p}<0.05$ compared with a fresh sample.

A

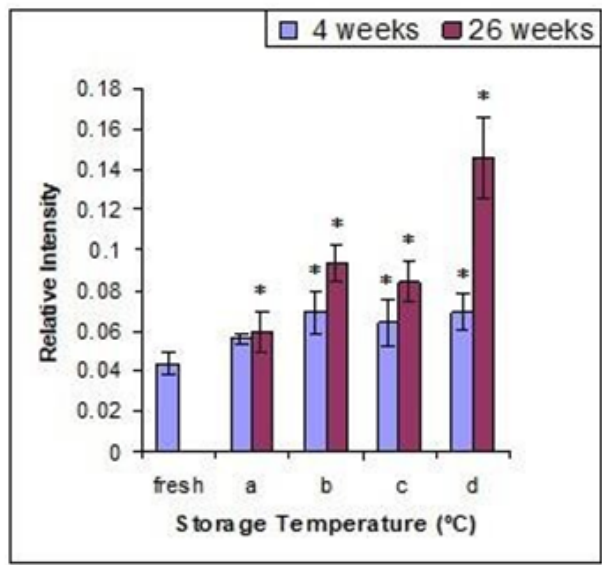

B

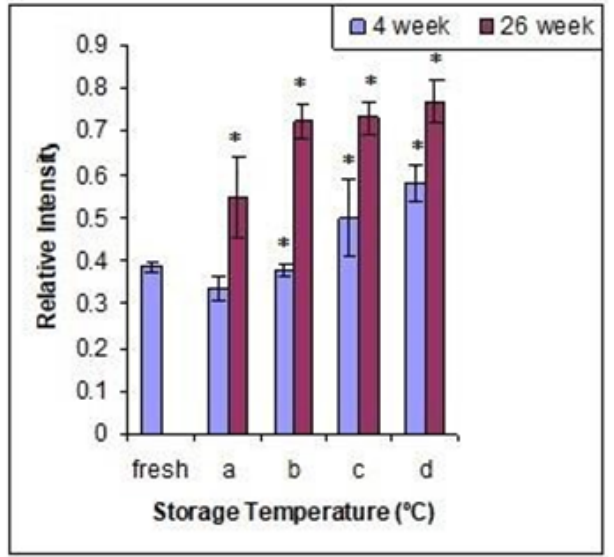

Fig. 7. B-sheet structure from Raman bands: (A) $990 \mathrm{~cm}^{-1}$ and (B) $1239 \mathrm{~cm}^{-1}$ for fresh and frozen mackerel stored for 26 weeks: (a) at $-80^{\circ} \mathrm{C}$, and at $-10^{\circ} \mathrm{C}$ with (b) $250 \mathrm{ppm}$ instant GT or (c) $500 \mathrm{ppm}$ instant GT, and (d) at $-10^{\circ} \mathrm{C}$ without instant GT. Each value is represented as mean $\pm \mathrm{SD}(\mathrm{n}=3), *$ indicates significance at $\mathrm{p}<0.05$ compared with a fresh sample.

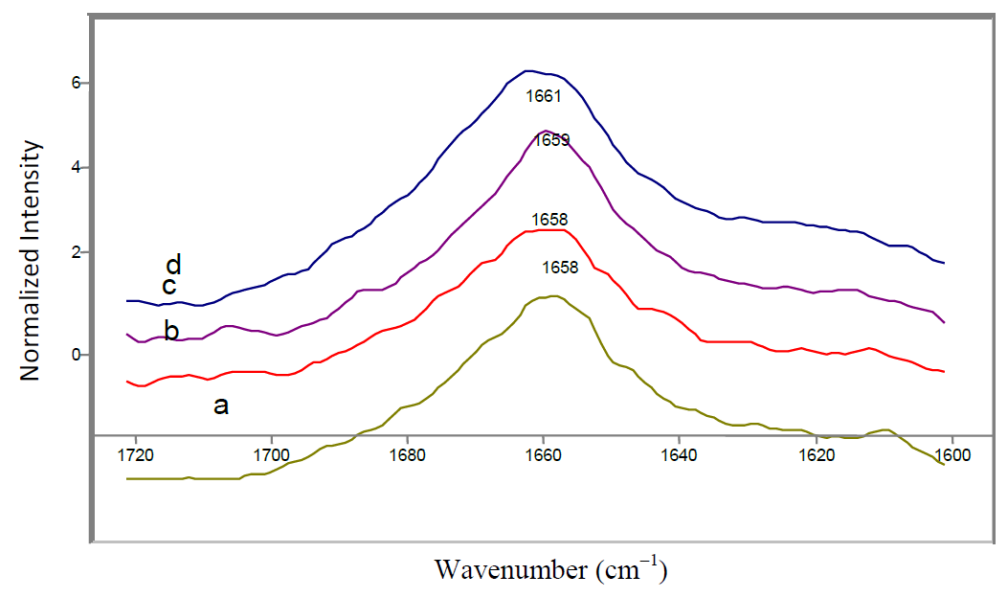

Fig. 8. Raman spectra in the amide I region of mackerel muscle stored for 26 weeks: (a) at $-80^{\circ} \mathrm{C}$, and at $-10^{\circ} \mathrm{C}$ with (b) $250 \mathrm{ppm}$ instant GT or (c) 500 ppm instant GT, and (d) at $-10^{\circ} \mathrm{C}$ without instant GT. 


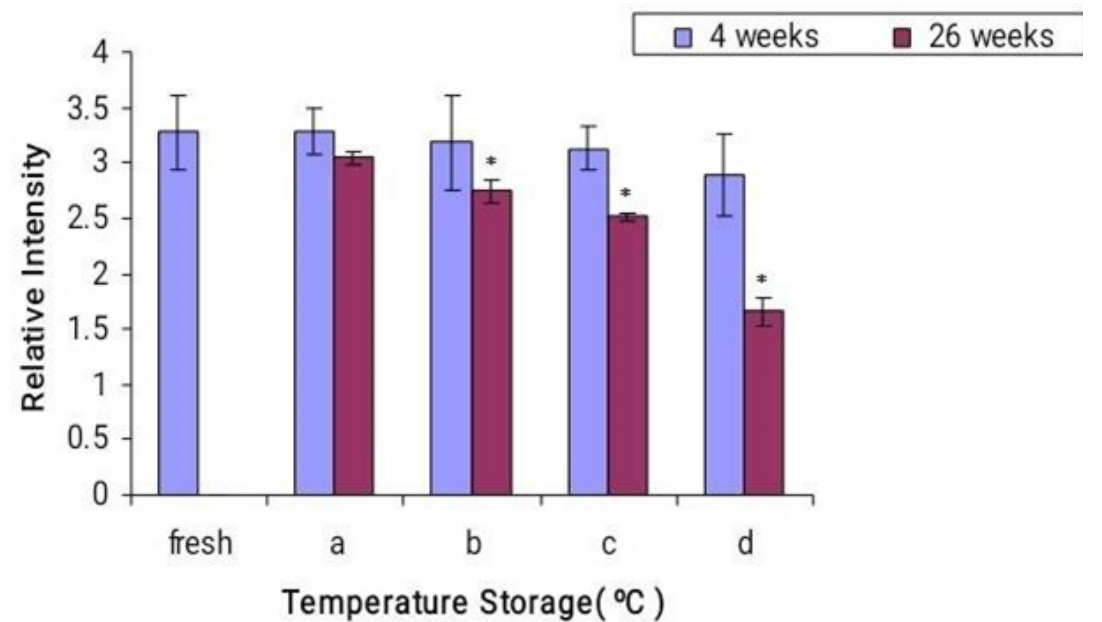

Fig. 9. Amide I region (1657-1662 $\left.\mathrm{cm}^{-1}\right)$ changes in fresh and frozen fish stored for up to 4 weeks and 26 weeks: (a) at $-80^{\circ} \mathrm{C}$, at $-10^{\circ} \mathrm{C}$ with (b) $250 \mathrm{ppm}$ instant $\mathrm{GT}$ or (c) $500 \mathrm{ppm}$ instant GT, and (d) at $-10^{\circ} \mathrm{C}$ without instant GT. Each value is represented as mean $\pm \mathrm{SD}(\mathrm{n}=3)$,

$*$ indicates significance at $\mathrm{p}<0.05$ compared with a fresh sample.

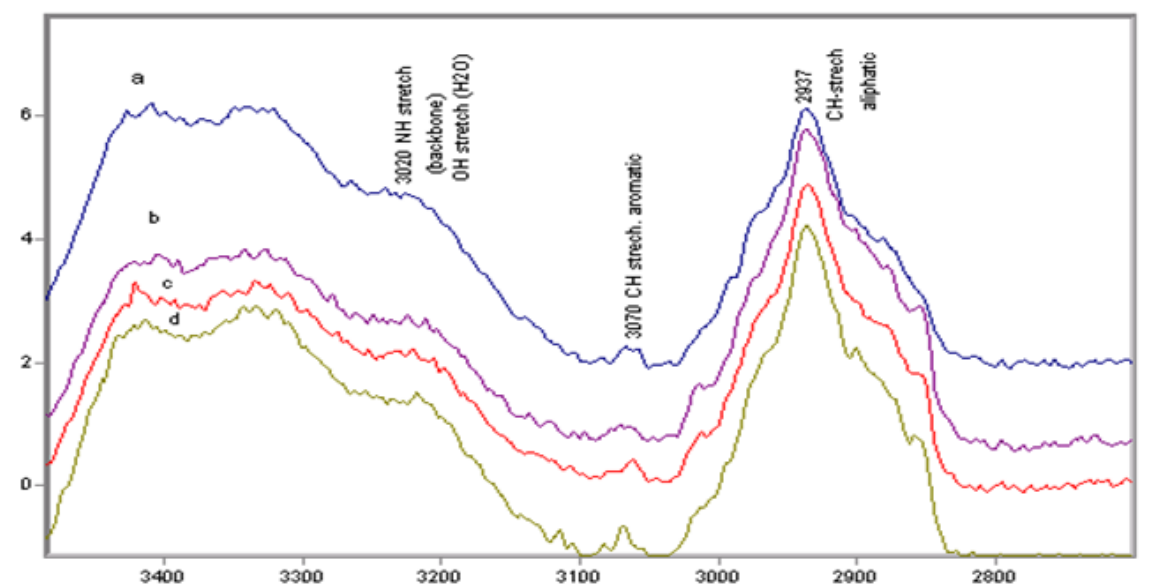

Fig. 10. Raman spectra (2800-3400 $\left.\mathrm{cm}^{-1}\right)$ of mackerel muscle stored for 26 weeks: (a) at $-80^{\circ} \mathrm{C}$, at $-10^{\circ} \mathrm{C}$ with (b) $250 \mathrm{ppm}$ instant GT or (c) $500 \mathrm{ppm}$ instant $\mathrm{GT}$, and (d) at $-10^{\circ} \mathrm{C}$ without instant GT.

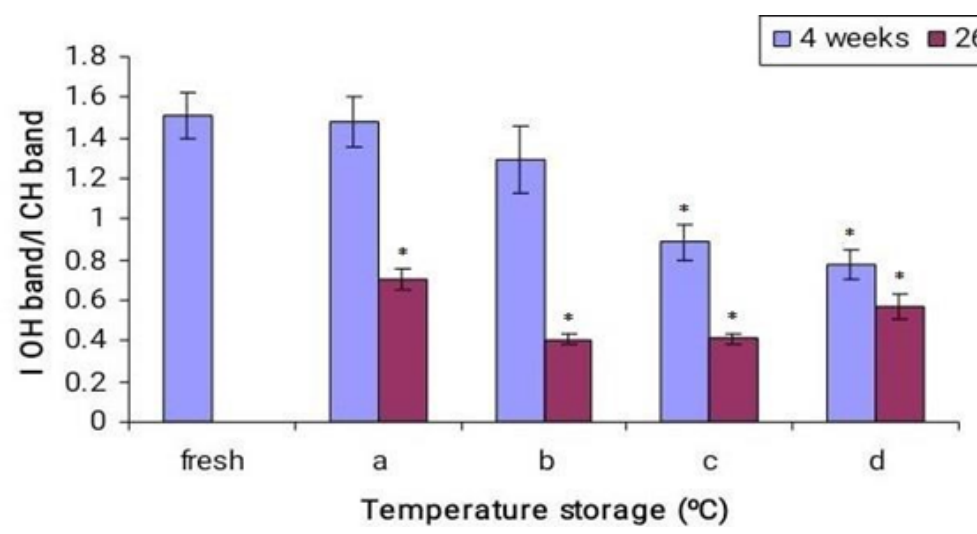

Fig. 11. Raman spectra $\mathrm{OH} / \mathrm{CH}$ stretching band ratio of fresh and frozen mackerel stored for 4 weeks and 26 weeks: (a) at $-80^{\circ} \mathrm{C}$, at $-10^{\circ} \mathrm{C}$ with (b) $250 \mathrm{ppm}$ instant $\mathrm{GT}$ or (c) $500 \mathrm{ppm}$ instant GT, and (d) at $-10^{\circ} \mathrm{C}$ without instant GT. Each value is represented as mean $\pm \mathrm{SD}(\mathrm{n}=3)$, $*$ indicates significance at $\mathrm{p}<0.05$ compared with a fresh sample. 
high levels of $\beta$-sheet istructure, it is centered at $1665-1657 \mathrm{~cm}^{-1}$. Coil structured proteins show the amide I band.

There was reduced amide I band intensity in all samples after 26 weeks compared with the result after 4 weeks, mainly in the group stored at $-10^{\circ} \mathrm{C}$ with no instant GT ( $p<0.01$ ). In contrast, the groups stored at -80 and $-10^{\circ} \mathrm{C}$ with instant GT showed fewer changes over time (Figure 9). After 26 weeks of frozen storage, there were significant differences in the intensity of the amide I band between the groups stored at $-10^{\circ} \mathrm{C}$ with no instant GT $(1.65 \pm 0.14)$ and that kept at $-80^{\circ} \mathrm{C}(3.04 \pm 0.05)(\mathrm{p}<0.01)$. Also, the intensity of the amide I band was significantly higher in samples treated with $250 \mathrm{ppm}$ instant GT than that of untreated samples stored at $-10^{\circ} \mathrm{C}(\mathrm{p}<0.05)$ (Figure 9).

Normal spectral of mackerel muscle stored for 10 and 26 weeks with and without instant GT in the $3400-2800 \mathrm{~cm}^{-1}$ region are shown in Figure 10. Bands at 2900, 2940, and $2980 \mathrm{~cm}^{-1}$ were assigned to $\mathrm{CH}$ stretching, including $\mathrm{CH}_{2}$ symmetric, $\mathrm{CH}_{2}$ asymmetric, and $\mathrm{CH}_{3}$ asymmetric stretching vibrations, respectively (Li-Chan et al., 1994), and the band at $3100-3500 \mathrm{~cm}^{-1}$ was assigned to $\mathrm{OH}$ stretching (Maeda \& Kitano, 1995).

A reduction was recorded in the $\mathrm{O}-\mathrm{H}$ stretching water band of $3100-3500$ $\mathrm{cm}^{-1}$, revealing water loss (Figure 10). For samples stored at $-80^{\circ} \mathrm{C}$, the $\mathrm{O}-\mathrm{H}$ band was more intense than the $\mathrm{C}-\mathrm{H}$ band. In contrast, in the group stored at $-10^{\circ} \mathrm{C}$ with no instant $\mathrm{GT}$, the $\mathrm{OH}$ band was significantly less intense than the $\mathrm{C}-\mathrm{H}$ band due to the loss of water and the exposure of proteins to the environment (Figure 11). O-H/C-H ratio can be used as a quality index to investigate the loss in quality resulting from storage under freezing conditions.

The efficacy of antioxidants depends on many factors, such as concentration, mixing ability and activity in different lipid systems, and stability over time during processing (Shahidi \& Zhong, 2011). It has also been found that very high levels of antioxidants act as pro-oxidants due to the regeneration of excessive levels of antioxidant free radicals (Sarkardei \& Howell, 2008). In the present study, $250 \mathrm{ppm}$ green tea was sufficient to prevent protein denaturation, while $500 \mathrm{ppm}$ green tea showed a lower protective effect, which may resulting from uneven or a loss in the mixing of antioxidants with the sample, aswell as its possibility of acting as a pro-oxidant agent.

\section{Conclusion}

There were substantial changes in the protein structure due to frozen storage, especially at the higher storage temperature $\left(-10^{\circ} \mathrm{C}\right)$, compared with $-80^{\circ} \mathrm{C}$ or $-10^{\circ} \mathrm{C}$ with instant GT. Raman spectra revealed protein denaturation, indicated by a decrease in the tyrosine doublet ratio, helix content, and $\mathrm{O}-\mathrm{H}$ stretching band intensities, and an increase in tryptophan band intensity and $\beta$-sheet structure. These changes may be attributable to ice formation, crystal growth pattern, and lipid peroxidation throughout freezing and frozen storage, as reported in previous studies (Badii et al., 2004). GT as an antioxidant, at a concentration of approximately $250 \mathrm{ppm}$, can protect the structure of fish proteins for a limited storage period. However, for optimal freshness, fish should be stored at very low temperatures.

\section{ACKNOWLEDGEMENTS}

The authors thank Dr Farah Badii at University of Surrey, UK; for her assistance, support, critical comments and suggestions to add more value to the research project (May she rest in peace). We also thank the Government of Libya for the financial and technical support. 


\section{References}

Ang, J.F. \& Hultin, H.O. (1989). Denaturation of cod myosin during freezing after modification with formaldehyde. Journal of Food Science, 54(4): 814-818.

Badii, F. \& Howell, N.K. (2000). Effect of antioxidants, citrate, and cryoprotectants on protein denaturation and texture of frozen cod (Gadus morhua). Journal of Agricultural and Food Chemistry, 50(7): 2053-2061.

Badii, F. \& Howell, N. K. (2002). Changes in the texture and structure of cod and haddock fillets during frozen storage. Food hydrocolloids, 16(4):313-9.

Badii, F.; Zhdan, P. \& Howell, N.K. (2004). Elucidation of protein aggregation in frozen cod and haddock by transmission electron microscopy/immunocytochemistr, light microscopy, and atomic force microscopy. Journal of the Science of Food and Agriculture, 84 (14):1919-28.

Bora, A.F.M.; Ma, S.; Li, X. \& Liu, L. (2018). Application of microencapsulation for the safe delivery of green tea polyphenols in food systems: Review and recent advances. Food Research International, 1(105): 241-9.

Byler, D.M. \& Susi, H. (1988). Application of computerized infrared and Raman spectroscopy to conformation studies of casein and other food proteins. Journal of Industrial Microbiology, 3(2):73-88.

Careche, M.; Herrero, A.M.; RodríguezCasado, A.; Del Mazo, M.L. \& Carmona, P. (1999). Structural changes of hake (Merluccius merluccius L.) Fillets: effects of freezing and frozen storage. Journal of Agricultural and Food Chemistry, 47 (3):952-959.
Colaianni, S.M. \& Nielsen, O.F. (1995). Low-frequency Raman spectroscopy. Journal of molecular structure, 347, 267283.

Diarrassouba, F.; Garrait, G.; Remondetto, G.; Alvarez, P. \& Beyssac, E. (2015). Subirade, M: Food protein-based microspheres for increased uptake of vitamin D3. Food Chemistry, 173, 1066-1072.

Elgamouz, A.; Alsaidi, R.; Alsaidi, A.; Zahri, M.; Almehdi, A. et al. (2019). The Effects of Storage on Quality and Nutritional Values of Ehrenberg's Snapper Muscles (Lutjanus Ehrenbergi): Evaluation of Natural Antioxidants Effect on the Denaturation of Proteins. Biomolecules, 9(9):442.

Fan, W.; Xing, L.; Chen, N.; Zhou, X.; Yu, Y. et al. (2019). Promotion Effect of Succinimide on Amyloid Fibrillation of Hen Egg-White Lysozyme. The Journal of Physical Chemistry B, 123(38):8057-64.

Herrero, A.M.; Carmona, P. \& Careche, M. (2004). Raman spectroscopic study of structural changes in hake (Merluccius Merluccius L.) muscle proteins during frozen storage. Journal of agricultural and food chemistry, 52(8):2147-53.

Howell, N. \& Li-Chan, E. (1996). Elucidation of interactions of lysozyme with whey proteins by Raman spectroscopy. International journal of food science \& technology, 31(5):439-51.

Howell, N.K.; Herman, H. \& Li-Chan, E.C. (2001). Elucidation of protein-lipid interactions in a lysozyme- corn oil system by Fourier transform Raman spectroscopy. Journal of Agricultural and Food Chemistry, 49 (3):1529-33. 
Hultin, H.O. \& Kelleher, S.D. (2000). Surimi processing from dark muscle fish. Food science and technology, New York, Marcel Dekker, 4, 59-78.

Jenkins, A.L.; Larsen, R.A. \& Williams, T.B. (2005). Characterization of amino acids using Raman spectroscopy. Spectrochimica Acta Part A: Molecular and Biomolecular Spectroscopy, 61 (7):1585-94.

Krimm, S. \& Bandek0ar, J. (1986). In Advances in protein chemistry. Elsevier, 38, 181-364.

Li-Chan, E. (1994). Developments in the detection of adulteration of olive oil. Trends in Food Science \& Technology, 5 (1): 3-11.

Li-Chan, E.; Nakai, S. \& Hirotsuka, M. (1994). Raman spectroscopy as a probe of protein structure in food systems. In Protein structure-function relationships in foods, 163-197. Springer, Boston, MA.

Maeda, Y. \& Kitano, H. (1995). The structure of water in polymer systems as revealed by Raman spectroscopy. Spectrochimica Acta Part A: Molecular and Biomolecular Spectroscopy, 51(14): 24332446.

Mandrile, L.; Zeppa, G.; Giovannozzi, A.M. \& Rossi, A.M. (2016). Controlling protected designation of origin of wine by Raman spectroscopy. Food Chemistry, 211, 260-267.

Miura, T.; Takeuchi, H. \& Harada, I. (1991). Raman spectroscopic characterization of tryptophan side chains in lysozyme bound to inhibitors: role of the hydrophobic box in the enzymic function. Biochemistry, 30 (24):6074-6080.
Ngarize, S.; Adams, A. \& Howell, N.K. (2004). Studies on egg albumen and whey protein interactions by FTRaman spectroscopy and rheology. Food Hydrocolloids, 18(1):49-59.

Ogawa, M.; Nakamura, S.; Horimoto, Y.; An, H.; Tsuchiya, T. et al. (1999). Raman spectroscopic study of changes in fish actomyosin during setting. Journal of agricultural and food chemistry, 47(8): 3309-3318.

Pereira de Abreu, D.A.; Maroto, J.; Villalba Rodríguez, K.\& Cruz,J.M.(2012). Antioxidants from barley husks impregnated in films of low-density polyethylene and their effect on lipid deterioration of frozen cod (Gadus morhua). Journal of the Science of Food and Agriculture, 92(2): 427-432.

Pokorný, J.; Yanishlieva, N. \& Gordon, M. (2001). Antioxidants in food: practical applications: Elsevier.

Romotowska, P.E.; Gudjónsdóttir, M.; Kristinsdóttir, T.B.; Karlsdóttir, M.G.; Arason, S. et al. (2016). Effect of brining and frozen storage on physicochemical properties of well-fed Atlantic mackerel (Scomber scombrus) intended for hot smoking and canning. LWT-Food Science and Technology, 72, 199-205.

Rudy, M.D.; Kainz, M.J.; Graeve, M.; Colombo, S.M. \& Arts, M.T. (2016). Handling and storage procedures have variable effects on fatty acid content in fishes with different lipid quantities. PloS one, 11(8): e0160497.

Saeed, S. \& Howell, N.K. (2002). Effect of lipid oxidation and frozen storage on muscle proteins of Atlantic mackerel (Scomber scombrus). Journal of the Science of Food and Agriculture, 82(5): 579-586. 
Saeed, S.; Gillies, D.; Wagner, G. \& Howell, N.K. (2006). ESR and NMR spectroscopy studies on protein oxidation and formation of dityrosine in emulsions containing oxidised methyl linoleate. Food and chemical toxicology, 44(8): 1385-1392.

Sarkardei, S. \& Howell, N. K. (2008). Effect of natural antioxidants on stored freeze-dried food product formulated using horse mackerel (Trachurus trachurus). International journal of food science \& technology, 43(2), 309-315.

Shahidi, F., \& Zhong, Y. (2011). Revisiting the polar paradox theory: a critical overview. Journal of agricultural and food chemistry, 59(8), 3499-3504.

Sharanagat, V.S., Kansal, V. \& Singh, L. (2019). Fish freezing: principle, methods, and scope. Technological Processes for Marine Foods, From Water to Fork: Bioactive Compounds, Industrial Applications, and Genomics, 97.

Sun, D.W. (2016). Handbook of frozen food processing and packaging. CRC press.

Tang, S.; Sheehan, D.; Buckley, D.J.; Morrissey, P.A. \& Kerry, J.P. (2001). Antioxidant activity of added tea catechins on lipid oxidation of raw minced red meat, poultry, and fish muscle. International journal of food science \& technology, 36 (6): 685-692.

Tu, A.T. (1986). Peptide backbone conformation and microenvironment of protein side chains. Advances in infrared and Raman spectroscopy, 13, 47-112.

Xiong, G.; Han, M.; Kang, Z.; Zhao, Y.; Xu, X. et al. (2016). Evaluation of protein structural changes and water mobility in chicken liver paste batters prepared with plant oil substituting pork back-fat combined with pre-emulsification. Food Chemistry, 196, 388-395.
Yamamoto, S.; Ohnishi, E.; Sato, H.; Hoshina, H.; Ishikawa, D. et al. (2019). Low-Frequency Vibrational Modes of Nylon 6 Studied by Using Infrared and Raman Spectroscopies and Density Functional Theory Calculations. The Journal of Physical Chemistry B, 123(25): 5368-5376.

$\begin{array}{lr}\text { Submitted: } & 12 / 13 / 2020 \\ \text { Revised: } & 12 / 07 / 2020 \\ \text { Accepted: } & 22 / 07 / 2020 \\ \text { DOI: } & 10.48129 / \text { kjs.v48i3.9339 }\end{array}$

